\title{
Phytochemical profile and ameliorative effect of fractions of methanol root bark extract of Afzelia africana (Smith) of family Fabeceae on libido, testosterone and sperm characteristics of diabetic male rats
}

\author{
Rita I Odo, Chukwuka N Uchendu \\ Department of Veterinary Physiology and Pharmacology, University of Nigeria, Nsukka, Nigeria
}

*For correspondence: Email: rita.odo@unn.edu.ng; Tel: +234-7033213630

Sent for review: 16 December 2017

Revised accepted: 19 July 2018

\begin{abstract}
Purpose: To evaluate the ameliorative potential of Afzelia africana (Smith) of family Fabeceae extract fractions on reproductive disorders associated with diabetes mellitus in diabetic male rats and the phytoconstituents of the active fraction.

Methods: Diabetic male rats were treated with the extract fractions and glibenclamide (standard antihyperglycemic agent) for 21 days, and their individual ameliorative effects on libido score (LS), testosterone level (TL), sperm motility (PSM) and epididymal sperm reserve (ESR) were determined and compared with those for diabetic untreated, and normal male rats.

Results: Optimum ameliorative potentials in respect of all the parameters measured were produced by fraction 3. There were significant increases in the results of fraction $3(p<0.05)$ when compared to the diabetic untreated group but did not differ significantly $(p>0.05)$ from those of normal non diabetic rats. The TL and ESR of glibenclamide-treated group did not differ significantly $(p>0.05)$ from fraction 3treated and normal groups but its LS and PSM decreased significantly, compared to fraction 3-treated group and normal rats. Phytochemical analysis of fraction 3 revealed the presence of flavonoids. Conclusion: Fraction 3 of the extract is a potential source of new classes of chemical agents that could be useful in ameliorating the reproductive dysfunction associated with diabetes in males.
\end{abstract}

Keywords: Diabetes, Sperm motility, Libido, Reproductive dysfunction, Afzelia africana, Glibenclamide

\footnotetext{
This is an Open Access article that uses a funding model which does not charge readers or their institutions for access and distributed under the terms of the Creative Commons Attribution License (http://creativecommons.org/licenses/by/4.0) and the Budapest Open Access Initiative (http://www.budapestopenaccessinitiative.org/read), which permit unrestricted use, distribution, and reproduction in any medium, provided the original work is properly credited.

Tropical Journal of Pharmaceutical Research is indexed by Science Citation Index (SciSearch), Scopus, International Pharmaceutical Abstract, Chemical Abstracts, Embase, Index Copernicus, EBSCO, African Index Medicus, JournalSeek, Journal Citation Reports/Science Edition, Directory of Open Access Journals (DOAJ), African Journal Online, Bioline International, Open-J-Gate and Pharmacy Abstracts
}

\section{INTRODUCTION}

Diabetes mellitus is a metabolic disease characterized by high blood glucose levels arising from inability of the pancreas to produce enough insulin or due to unresponsive body cells to insulin that is produced [1]. The common clinical signs of diabetes mellitus are polyuria, polydipsia, polyphagia and weight loss [2]. Reduced reproductive functions have been widely reported in both diabetic man and animals. About $90 \%$ of diabetic males have low performance in sexual activities including decreases in libido, sperm count and sperm motility as a result of sustained hyperglycemia [3]. After 2 weeks of induction of diabetes in male 
rats, significant decreases in sperm count and motility have been reported [4]. Oxidative stress induced by hyperglycemia is the major cause of diabetic sperm damage as oxidative stress is increased in diabetes, due to overproduction of reactive oxygen species (ROS), and decreased efficiency of antioxidant defenses $[5,6]$.

Afzelia africana is a plant consumed in most households as thickening agent in the South Eastern part of Nigeria. It belongs to the family of Fabaceae. Its English name is "African mahogany". Its Ivorian name is "lingue". It is called "Kankalga" in More and "Lingahi" in Fulfulde. In Nigeria, it is called "akpalata" in Igbo, "kawo" in Hausa and "apa" in Yoruba [7].

The stem-bark extract of Afzelia africana possesses antihyperglycemic activity [8], which was also confirmed in the root bark extract [9]. However, there is paucity of information on the antihyperglycemic effects of the different fractions of the extract, ameliorative potentials of the fractions on reproductive dysfunctions associated with diabetes mellitus and the phytochemical constituent of the active fraction or fractions.

The aim of this study was, therefore, to determine the antihyperglycemic and ameliorative effects of the different fractions of the extract and then find out the phytochemical constituent of the active fraction.

\section{EXPERIMENTAL}

\section{Plant collection and identification}

Fresh samples of the plant were collected from a local herbalist who claimed to use the plant in the management of the symptoms and complications of diabetes mellitus in Ogbadibo Local Government Area of Benue State, Nigeria in September 2011. The fresh plant samples were identified as Afzelia africana by a taxonomist, $\mathrm{Mr}$ AO Ozioko, of the Bioresources Development and Conservation Programme, Aku Road, Nsukka, Enugu State, Nigeria, where voucher specimen was deposited in INTERCEDD (International Center for Ethnomedicine and Drug Development) herbarium INTERCEDD/1597).

\section{Preparation of plant extract}

The fresh root bark of Afzelia africana was dried at room temperature in a ventilated room. It was pulverized using mortar and pestle into coarse powder. The material was finely ground with a grinding machine. Two kilograms $(2 \mathrm{~kg})$ of the powdered root bark was defatted using absolute hexane with intermittent shaking at intervals of 2 $\mathrm{h}$ for $48 \mathrm{~h}$. Cold extraction of the defatted root bark was performed using $80 \%$ methanol with intermittent shaking at intervals of $2 \mathrm{~h}$ for $48 \mathrm{~h}$. The extract was filtered with Whatman no. 1 filter paper and concentrated using rotary evaporator.

\section{Fractionation of plant extract}

\section{Column chromatography}

Silica gel $\left(\mathrm{GF}_{254}\right)$ was used as stationary phase while gradient solvent system of the combination of chloroform, ethyl acetate and methanol was used as the mobile phase in the ratio of $3: 2: 1$. The column was packed with silica gel. Extract sample which was put uniformly to the top of the column for fractionation was prepared by mixing $10 \mathrm{~g}$ of crude extract with $40 \mathrm{~g}$ of silica gel. Elution was done with $500 \mathrm{ml}$ each of hexane, chloroform, ethyl acetate and methanol. The fractions were collected (10 $\mathrm{ml}$ per test tube) sequentially in labeled test tubes as the solvent dripped from the bottom of the column [10].

\section{Thin layer chromatography}

Thin layer chromatography (TLC) plate $\left(\mathrm{GF}_{254}\right.$ precoated aluminum plate) was cut into smaller sizes of $10 \mathrm{~cm}$ by $5 \mathrm{~cm}$, spotted with the fraction from each test tube collected from the column chromatography and developed in a chamber containing a shallow pool of a predetermined solvent system. The plates were air-dried, visualized using ultraviolet (UV) light and the distance traveled by each fraction was marked and used to compute the retention factor $\left(R_{f}\right)$ value for each fraction.

Fractions with the same $R_{f}$ values were pooled together as one fraction [10], concentrated and stored in a refrigerator.

\section{Animals}

Forty eight mature male and thirty two mature female Albino Wistar rats (Rattus norvergicus) of 12 weeks of age weighing between 180 to $200 \mathrm{~g}$ were used for the study. They were obtained from Laboratory Animal Unit of the Faculty of Veterinary Medicine, University of Nigeria, Nsukka, Nigeria. Handling of the experimental animals was in accordance with Principles of laboratory animal care (NIH publication no. 8523; revised 1985) and was approved by the Ethical Committee of Faculty of Veterinary Medicine, University of Nigeria, Nsukka (approval ref no. 20120815). The handling complied with Directive 2012/52/WE on the use of animals for experiments [11]. 


\section{Induction of diabetes and treatment}

Experimental diabetes was induced with alloxan monohydrate at the dose of $150 \mathrm{mg} / \mathrm{kg}$ dissolved in distilled water, intraperitoneally in 7 groups of male rats with 6 rats per group. Animals with fasting blood sugar (FBS) level above 6.4 $\mathrm{mmol} / \mathrm{L}$ after ten days post induction were considered to be diabetic [12] . The fractions obtained from column and thin layer chromatograghy were used to treat groups 1 to 5 at the dose of $50 \mathrm{mg} / \mathrm{kg}$ dissolved in distilled water orally using gastric gavage. Groups 6, 7 and 8 were the glibenclamide $(2 \mathrm{mg} / \mathrm{kg}$ dissolved in distilled water orally) treated, untreated diabetic (given distilled water, $10 \mathrm{ml} / \mathrm{kg}$ orally) and normal (given distilled water, $10 \mathrm{ml} / \mathrm{kg}$ orally) male rats respectively.

The treatment was daily for 21 days. Fasting blood sugar (FBS) levels were determined at 0 hour (before treatment) and on days 7, 14 and 21. At the end of the 21 day treatment period, the reproductive parameters were determined as follows:

\section{Determination of libido}

Each male rat from all the groups was paired with two female rats confirmed to be in estrus in turn and was given 10 minutes for performance. Within the 10 minutes, the rats were scored as follows: 0 - showed no sexual interest, 1 showed sexual interest only once, 2 - showed positive sexual interest in female on more than one occasion, 3 - was in active pursuit of female with persistent sexual interest, 4 - had one mount or mounting attempt without service, 5 had two mounts or mounting attempts without service, 6 - had more than two mounts or mounting attempts without service, 7 - had one service followed by no further sexual interest, 8 had one service followed by further sexual interest including mounts or mounting attempts, 9 - had two services followed by no further sexual interest and 10 - had two services followed by sexual interest including mounts, mounting attempts or further service [13].

\section{Determination of testosterone level}

Serum samples from the rats were subjected to testosterone assay using Enzyme Linked Immunosorbent Assay (ELISA) [14].

\section{Evaluation of sperm motility}

The tail of epididymis was punctured with a needle and a drop of sperm was placed on a pre- warmed clean slide with the application of pressure on the epididymis. Thereafter, two drops of warm $2.9 \%$ sodium citrate were added to the sperm sample. This was covered with a cover slip and viewed under the microscope at $\times 40$ magnification for percentage of motile sperms [14].

\section{Determination of epididymal sperm reserve}

The left and right caudal epididymis were crushed separately with ceramic mortar and pestle, $5 \mathrm{ml}$ of normal saline added to each and filtered through a nylon sieve. Each filtrate $(0.1$ $\mathrm{ml}$ ) was further diluted with $0.9 \mathrm{ml}$ of white blood cells diluting fluid in a test tube and $20 \mu \mathrm{l}$ of each diluted sperm solution was used to charge the Improved Neubauer chamber and viewed under the microscope at $\times 10$ magnification.

The number of sperm cells were counted on the four corner squares and estimated in 169 squares. The sperm cells counted in 169 squares of the Neubauer chamber were in $2.5 \times 10^{-4} \mathrm{ml}$ which was the volume of the Neubauer chamber. The number of sperm cells counted in each sample was multiplied by 5 to get the total number of sperm cells in the original volume of sperm samples [16,17].

\section{Phytochemical analysis of the active fraction}

Phytochemical tests were carried out on fraction 3 using standard procedures for the presence of tannins (Stiasny test and ferric chloride test) [18], glycosides (Borntraega test), alkaloids (Bouchardat, Valser-Mayer and Dragendorff's reagent test), flavonoids (Shibata's test), and saponins (Frothing test and Emulsifying test) [19].

\section{Statistics}

Data obtained from the study were statistically analysed using one way analysis of variance (ANOVA). The variant means were separated using Duncan Multiple Range Test. Level of significant was accepted at $p<0.05$. The data were expressed in tables.

\section{RESULTS}

\section{Extract yield and fractions}

Extraction of $2000 \mathrm{~g}$ of powdered stem bark material produced $194 \mathrm{~g}$ of dried extract representing a yield of $9.7 \%$. The column and thin layer chromatography revealed the presence of five fractions in the extract. 


\section{Induction of diabetes}

Conclusive evidence that diabetes mellitus was successfully induced was shown by tremendous increase in mean FBS levels above $6.4 \mathrm{mmol} / \mathrm{L}$ $(0 \mathrm{~h}, \mathrm{FBS}$ level) of the rats post-induction (Table 1).

\section{Antihyperglycemic activities of the fractions}

Fraction 3 produced optimum anti-hyperglycemic activity throughout the study period just as the glibenclamide (Table 1). The percentage FBS reduction of fraction 3 was $75.5 \%$ while that of glibenclamide was $80.2 \%$. This confirms the antihyperglycemic potential of fraction 3 .

\section{Ameliorative potential of the fractions on diabetic male reproductive dysfunction}

The ability of the fractions to ameliorate diabetesinduced reproductive dysfunction was evaluated using libido score (LS) (Table 2), testosterone level (TL) (Table 3), percentage sperm motility (PSM) (Table 4) and epididymal sperm reserve (ESR) (Table 5). Optimum ameliorative potential on all the parameters measured was produced by fraction 3 . The parameters of fraction 3 increased significantly $(p<0.05)$ when compared to the diabetic untreated group. The reproductive parameters of fraction 3 treated group did not differ significantly $(p>0.05)$ from those of normal non-diabetic rats. The TL, and right ESR of glibenclamide treated group did not differ significantly $(p>0.05)$ from fraction 3 treated group and normal rats but its LS and PSM decreased significantly when compared to fraction 3 treated group and the normal rats.

\section{Phytochemical profile of fraction 3}

Test to ascertain the phytochemical constituents of fraction 3 revealed presence of flavonoids. Tannins, alkaloids, saponins and glycosides were absent.

Table 1: Mean weekly FBS levels of the fractions' treatment for 21 days ( \pm SEM)

\begin{tabular}{|c|c|c|c|c|c|c|c|}
\hline Group & Treatment & $\begin{array}{c}\text { FBS } \\
0 \mathrm{~h} \\
\end{array}$ & $\begin{array}{c}\text { FBS Day } \\
1 \\
\end{array}$ & $\begin{array}{c}\text { FBS Day } \\
7 \\
\end{array}$ & $\begin{array}{c}\text { FBS Day } \\
14\end{array}$ & $\begin{array}{c}\text { FBS Day } \\
21\end{array}$ & $\begin{array}{c}\text { FBS } \\
\text { reduction (\%) }\end{array}$ \\
\hline 1 & Fraction 1 (50) & $\begin{array}{r}15.26 \\
\pm 1.43^{a}\end{array}$ & $\begin{array}{c}14.88 \\
\pm 0.90^{\mathrm{a}}\end{array}$ & $\begin{array}{c}14.87 \\
\pm 0.89^{\mathrm{a}}\end{array}$ & $\begin{array}{c}15.00 \\
\pm 0.91^{\mathrm{a}}\end{array}$ & $\begin{array}{c}14.89 \\
\pm 0.92^{a}\end{array}$ & 2.4 \\
\hline 2 & Fraction 2 (50) & $\begin{array}{r}12.86 \\
\pm 1.22^{a}\end{array}$ & $\begin{array}{r}12.22 \\
\pm 1.04^{a}\end{array}$ & $\begin{array}{r}12.89 \\
\pm 0.59^{a}\end{array}$ & $\begin{array}{r}12.90 \\
\pm 0.40^{a}\end{array}$ & $\begin{array}{c}12.21 \\
\pm 0.43^{a}\end{array}$ & 5.0 \\
\hline 3 & Fraction 3 (50) & $\begin{array}{r}20.84 \\
\pm 1.30^{\mathrm{a}}\end{array}$ & $\begin{array}{r}4.16 \\
\pm 1.09^{b}\end{array}$ & $\begin{array}{r}4.22 \\
\pm 0.89^{b}\end{array}$ & $\begin{array}{r}4.20 \\
\pm 0.50^{b}\end{array}$ & $\begin{array}{c}4.17 \\
\pm 0.42^{b}\end{array}$ & 78.7 \\
\hline 4 & Fraction 4 (50) & $\begin{array}{r}20.42 \\
\pm 1.04^{\mathrm{a}}\end{array}$ & $\begin{array}{r}19.64 \\
\pm 0.56^{a}\end{array}$ & $\begin{array}{c}18.99 \\
\pm 0.36^{a}\end{array}$ & $\begin{array}{c}19.10 \\
\pm 0.19^{\mathrm{a}}\end{array}$ & $\begin{array}{c}19.61 \\
\pm 0.15^{\mathrm{a}}\end{array}$ & 3.9 \\
\hline 5 & Fraction 5 (50) & $\begin{array}{r}15.00 \\
\pm 1.03^{a}\end{array}$ & $\begin{array}{r}14.40 \\
\pm 1.30^{a}\end{array}$ & $\begin{array}{c}13.99 \\
\pm 0.75^{a}\end{array}$ & $\begin{array}{c}14.98 \\
\pm 0.37^{a}\end{array}$ & $\begin{array}{r}14.50 \\
\pm 0.26^{a}\end{array}$ & 3.3 \\
\hline 6 & Glibenclamide (2) & $\begin{array}{c}20.20 \\
\pm 1.22^{\mathrm{a}}\end{array}$ & $\begin{array}{c}3.98 \\
\pm 1.05^{b}\end{array}$ & $\begin{array}{r}4.20 \\
\pm 0.59^{b}\end{array}$ & $\begin{array}{r}4.98 \\
\pm 0.40^{b}\end{array}$ & $\begin{array}{c}4.01 \\
\pm 0.43^{b}\end{array}$ & 80.1 \\
\hline 7 & UD & $\begin{array}{r}14.46 \\
\pm 0.59^{a}\end{array}$ & $\begin{array}{r}16.08 \\
\pm 0.77^{\mathrm{a}}\end{array}$ & $\begin{array}{r}15.70 \\
\pm 1.48^{\mathrm{a}}\end{array}$ & $\begin{array}{r}15.80 \\
\pm 1.19^{a}\end{array}$ & $\begin{array}{r}16.50 \\
\pm 0.32^{a}\end{array}$ & - \\
\hline
\end{tabular}

Key: $a, b=$ Different superscripts indicate differences between the mean $(p<0.05)$. $O \mathrm{~h}=$ before treatment, UD = untreated diabetic, - = no reduction

Table 2: Mean libido scores of diabetic male rats after 21 days of treatment with the fractions ( \pm SEM)

\begin{tabular}{lcccccccc}
\hline Parameter & \multicolumn{8}{c}{ Treatment } \\
\hline & F1 & F2 & F3 & F4 & F5 & Gilb & UD & Normal \\
\hline Libido score & 1.40 & 1.80 & 7.20 & 1.80 & 1.20 & 4.60 & 0.40 & 7.80 \\
& $\pm 0.24^{\mathrm{a}}$ & $\pm 0.37^{\mathrm{b}}$ & $\pm 0.20^{\mathrm{c}}$ & $\pm 0.37^{\mathrm{b}}$ & $\pm 0.37^{\mathrm{a}}$ & $\pm 0.24^{\mathrm{d}}$ & $\pm 0.24^{\mathrm{a}}$ & $\pm 0.37^{\mathrm{c}}$ \\
\hline
\end{tabular}

Key: $a, b, c, d \rightarrow$ Different superscripts indicate difference between the means $(p<0.05)$. F1 $\rightarrow$ fraction $1, F 2 \rightarrow$ fraction 2, F3 $\rightarrow$ fraction 3, F4 $\rightarrow$ fraction 4 , F5 $\rightarrow$ fraction 5 , Gilb $\rightarrow$ glibenclamide, UD $\rightarrow$ untreated diabetic

Table 3: Mean testosterone levels (TL) of diabetic male rats after 21 days of treatment $( \pm \mathrm{SEM})$

\begin{tabular}{ccccccccc}
\hline Parameter & \multicolumn{7}{c}{ Treatment } \\
\hline TL (ng/ml) & F1 & F2 & F3 & F4 & F5 & Gilb & UD & Normal \\
& 0.35 & 0.33 & 2.00 & 0.33 & 0.33 & 1.98 & 0.27 & 2.88 \\
& $\pm 0.02^{\mathrm{a}}$ & $\pm 0.01^{\mathrm{a}}$ & $\pm 0.29^{\mathrm{b}}$ & $\pm 0.09^{\mathrm{a}}$ & $\pm 0.00^{\mathrm{a}}$ & $\pm 0.25^{\mathrm{b}}$ & $\pm 0.05^{\mathrm{a}}$ & $\pm 0.92^{\mathrm{b}}$ \\
\hline
\end{tabular}

Key: $a, b \rightarrow$ Different superscripts indicate difference between the means $(p<0.05)$. TL $\rightarrow$ testosterone level, $F 1 \rightarrow$ fraction $1, \mathrm{~F} 2 \rightarrow$ fraction $2, \mathrm{~F} 3 \rightarrow$ fraction $3, \mathrm{~F} 4 \rightarrow$ fraction $4, \mathrm{~F} 5 \rightarrow$ fraction 5 , Gilb $\rightarrow$ glibenclamide, UD $\rightarrow$ untreated diabetic 
Table 4: Mean sperm motility (\%) of diabetic male rats after 21 days of treatment $( \pm$ SEM)

\begin{tabular}{|c|c|c|c|c|c|c|c|c|}
\hline Parameter & & & & & ment & & & \\
\hline & $F 1$ & F2 & F3 & F4 & $F 5$ & Gilb & $U D$ & Normal \\
\hline PSM (\%) & $\begin{array}{l}13.33 \\
\pm 3.33^{a}\end{array}$ & $\begin{array}{l}30.0 \\
\pm 5.77^{b}\end{array}$ & $\begin{array}{l}66.67 \\
\pm 3.33^{\mathrm{C}}\end{array}$ & $\begin{array}{l}14.33 \\
\pm 3.33^{a}\end{array}$ & $\begin{array}{l}13.33 \\
\pm 3.33^{a}\end{array}$ & $\begin{array}{l}25.00 \\
\pm 2.89^{b}\end{array}$ & $\begin{array}{l}13.33 \\
\pm 3.33^{a}\end{array}$ & $\begin{array}{l}73.33 \\
\pm 3.33^{c}\end{array}$ \\
\hline
\end{tabular}

Table 5: Mean epididymal sperm reserve of diabetic male rats after 21 days of treatment $( \pm$ SEM)

\begin{tabular}{|c|c|c|c|c|c|c|c|c|}
\hline \multirow[t]{2}{*}{ Parameter } & \multicolumn{8}{|c|}{ Treatment } \\
\hline & $F 1$ & F2 & F3 & F4 & $F 5$ & Glib & $U D$ & Normal \\
\hline LESR $\left(\times 10^{6}\right)$ & 28.90 & 27.59 & 48.85 & 27.92 & 27.10 & 48.14 & 24.46 & 54.55 \\
\hline & $\pm 1.29^{\mathrm{a}}$ & $\pm 0.63^{a}$ & $\pm 4.39^{\mathrm{b}}$ & $\pm 0.93^{a}$ & $\pm 0.10^{\mathrm{a}}$ & $\pm 4.62^{\mathrm{b}}$ & $\pm 1.94^{\mathrm{a}}$ & $\pm 4.66^{\mathrm{b}}$ \\
\hline $\operatorname{RESR}\left(\times 10^{6}\right)$ & $\begin{array}{r}26.27 \\
\pm 1.01^{a}\end{array}$ & $\begin{array}{c}27.89 \\
\pm 1.14^{\text {a }}\end{array}$ & $\begin{array}{r}48.90 \\
\pm 4.39^{b}\end{array}$ & $\begin{array}{c}27.89 \\
\pm 0.30^{a}\end{array}$ & $\begin{array}{c}26.76 \\
\pm 0.58^{a}\end{array}$ & $\begin{array}{r}48.52 \\
\pm 4.39^{b}\end{array}$ & $\begin{array}{r}25.35 \\
\pm 1.94^{\mathrm{a}}\end{array}$ & $\begin{array}{r}53.62 \\
\pm 2.76^{b}\end{array}$ \\
\hline
\end{tabular}

Key: $a, b \rightarrow$ Different superscripts indicate difference between the means $(p<0.05)$. LESR $\rightarrow$ left epididymal sperm reserve, RESR $\rightarrow$ right epididymal sperm reserve,F1 $\rightarrow$ fraction $1, F 2 \rightarrow$ fraction $2, F 3 \rightarrow$ fraction 3 , $F 4 \rightarrow$ fraction $4, F 5 \rightarrow$ fraction 5 , Gilb $\rightarrow$ glibenclamide, UD $\rightarrow$ untreated diabetic

\section{DISCUSSION}

The results of the antihyperglycemic activity of the fractions determined weekly revealed that fraction 3 was responsible for the antihyperglycemic activity of the methanol root bark extract of Afzelia africana. Its antihyperglycemic potential may be due to its capability to restore the normal functioning of the pancreas, induce insulin secretion, induce glycolysis or reduce glucose absorption in the intestine. Glibenclamide, the reference drug, acts by inducing insulin secretion.

The observed decreases in libido score, testosterone level, percentage sperm motility and epididymal sperm reserve in the untreated diabetic male rats in this study are in line with earlier reports. These decreases may be due to sustained hyperglycemia throughout the study period and its associated oxidative stress.

The significant decrease $(p<0.05)$ in libido score of the untreated diabetic rats when compared to those of the fraction 3 treated diabetic rats may be attributed to the significant decrease in testosterone level. Testosterone is responsible for maintenance of libido in males [20]. It may also be due to erectile dysfunction. Decrease in libido as seen in diabetic males in this study, may contribute to their erectile dysfunction [21]. Erectile dysfunction is caused by vascular dysfunction. Endothelial-derived vasorelaxation is gradually lost in diabetics due to oxidative stress induced by hyperglycemia [22].

The significant decreases $(p<0.05)$ in left ESR and right ESR of untreated diabetic rats when compared to the fraction 3 treated diabetic rats' left ESR and right ESR may be associated with decrease in testosterone level. Testosterone is essential for normal sperm development.

The significant decrease $(p<0.05)$ in libido score of glibenclamide treated group when compared to fraction 3 treated group, may be due to vascular endothelial dysfunction that may not have been protected by glibenclamide and this may have led to erectile dysfunction that manifested as decreased libido. The glibenclamide treated group mounted the female one to two times without service. Diabetes mellitus is associated with an induction of vascular endothelial dysfunction caused by oxidative stress - an initial event that could lead to the pathogenesis of erectile dysfunction.

The significant decrease in percentage sperm motility of glibenclamide treated group when compared to fraction 3 treated group may be due to reactive oxygen attack as glibenclamide is not an antioxidant but only an antihyperglycemic agent. Phytochemical analysis of fraction 3 revealed presence of flavonoids. Flavonoids are antioxidants [23,24]. This may therefore explain the demonstration of antioxidant activity of Fraction 3. Flavonoids scavenge free oxygen radicals hence, important in managing diseases associated with oxidative damage such as diabetes mellitus.

Diabetes has adverse effect on sperm quality through the induction of oxidative stress and at the same time disrupts the testicular antioxidant status. Fraction 3 was very important in this defensive, mechanism. Its ability to ameliorate this pathology shows its efficacy in overcoming oxidative stress in this context. The sperm 
plasma membrane is very sensitive to the effect of reactive oxygen since it contains abundant unsaturated fatty acids. These unsaturated fatty acids provide fluid which is necessary for sperm motility [25].

\section{CONCLUSION}

The ameliorative potential of fraction 3 of the methanol root bark extract of Afzelia africana on reproductive dysfunction in diabetic male rats and its antihyperglycemic activity demonstrate that this fraction is a potential source of new chemical agents that could be helpful in the management of diabetes mellitus in males but further studies are required to ascertain this.

\section{DECLARATIONS}

\section{Acknowledgement}

We are grateful to Prof IU Asuzu for his valuable contribution to this work.

\section{Conflict of interest}

No conflict of interest was associated with this work.

\section{Contribution of authors}

We declare that this work was done by us, Rita I. Odo and Chukwuka N. Uchendu and all liabilities pertaining to claims relating to the content of this article will be borne by us. Rita I. Odo and Chukwuka N. Uchendu conceived and designed the work. Rita I. Odo collected and analysed the data. Rita I. Odo wrote the manuscript and Chukwuka N. Uchendu revised the manuscript critically. Both authors read and approved the manuscript for publication.

\section{REFERENCES}

1. Rother KI. Diabetes Treatment - bridging the divide. $N$ Engl J Med 2007; 356 (15): 1499-1501.

2. Cooke DW, Plotnick L. "Type 1 diabetes mellitus in pediatrics. Pediatr Rev 2008; 29 (11): 374-384.

3. AbuAbeeleh M, Bani Ismail Z, Alzaben KR, Abu-Halaweh SA, Al-Essa MK, Abu Abeeleh J. Induction of Diabetes Mellitus in Rats Using Intraperitoneal Streptozotocin: A Comparison between 2 Strains of Rats. Eur J Sci Res 2009; 32 (3): 398-402.

4. Benitez A, Perez D. Effect of streptozotocin-diabetes and insulin treatment on regulation of Leydig cell function in the rat Horm Metab Res 1985; $17: 5-7$

5. Zhao Y, Tan Y, Dai J, Li B, Guo L, Cui J, Wang G, Shi X, Zhang $X$, Mellen $N$ et al. Exacerbation of diabetes- induced testicular apoptosis by zinc deficiency is most likely associated with oxidative stress, p38 MAPK activation, and p53 activation in mice. Toxicol Lett. 2011; 200: 100-106.

6. Ballester J, Munoz MC, Dominguez J, Rigau T, Guinovart $J J$, Rodriguez-Gil JE. Insulin dependent diabetes affects testicular functions by $\mathrm{FSH}$ and $\mathrm{LH}$-linked mechanisms. $J$ Androl 2004; 25): 706-719.

7. Odo RI, Mbegbu EC, Aka LO, Ezeasor CK, Nnajiofor VA, Obidike IR. The protective effect of the methanolic root bark extract of Afzelia africana on conception and fetal development in diabetic female rats. J Comp Clin Pathol 2016; 25 (4): 705-711.

8. Oyedemi SO, Adewusi EA, Aiyegoro OA, Akinpelu DA. Antidiabetic and haematological effect of aqueous extract of stem bark of Afzelia africana (Smith) on streptozotocin -induced diabetic Wister rats. Asian Pac J Trop Biomed 2011; 1(5): 353-358.

9. Odo RI, Asuzu IU, Aba PE. The antidiabetic Activities of the methanolic root bark extract of Afzelia Africana in alloxan-induced Diabetic Mice. J Complement Integr Med 2012; 9(1): 1553-3840.

10. Stahl Ergon (1969). Thin layer chromatography. A laboratory handbook, 2nd edition. New York: springerVerlag; 1969; $p$ 88-120.

11. Ward JW, Elsea JR. Animal case and use in drug fate and metabolism. Methods and techniques, Vol 1. New York: 1997; p 372-390.

12. Venugopal PM, Prince PS, Pan L. Hypoglycemic activity of Syzigium cumini seeds: effect on lipid perodixation in alloxan diabetic rats. $J$ Ethnopharmacol 1988; 61: 1-7.

13. Chenoweth PI, Brinks IS, Nett TM. A comparison of three methods of assessing sex-drive in yearling beef bulls and relationships with testosterone and $L H$ levels. Theriogenol 1979; 12: 223.

14. Swaran JS, Flora S, Pande M, Mehta A. Beneficial effects of combined administration of some naturally occurring antioxidants (vitamins) and thiol chelators in the treatment of chronic lead intoxication. Chemico-Bio Inter 2003; 145(3): 267-280.

15. Morrissey RE, Schwetz BA, Lamb JC, Ross MD, Teague $J L$, Moris RW. Evaluation of rodent sperm, vaginal cytology and reproductive organ weight data. Fundam Appl Toxicol 1988; 11 (2): 343-358.

16. Odo Rl, Mbegbu EC, Nwosu KC, Aba PE, Aka LO, Obidike IR. Effect of cement dust on reproductive performance and some physiological parameters in albino rats. J Comp Clin Pathol 2015; 24 (3): 521-526.

17. Amann RP. Detection of alteration in testicular and epididymal function in laboratory animals. Environ Heal Perspect 1986; 70: 119-158

18. Saminathan $M$, Sieo CC, Gan HM, Ravi $S$, Venkatachalam K, Abdullah N, Michael C, Wong CM, Ho YW. Modulatory effects of condensed tannin fractions of different molecular weights from a Leucaena leucocephala hybrid on the bovine rumen bacterial community in vitro. J Sci Food Agric 2016; 96 (13): 4565-4574.

Trop J Pharm Res, August 2018; 17(8):1554 
19. Harborne JB. Phytochemical Methods - A Guide to Modern Techniques of plant analysis. London: Chapman and Hall; 1998; pp 129-134.

20. Olayemi FO. A review on some causes of male infertility. Afric J Bioech 2010; 9 (20): 2834 - 2842.

21. Palumbo PJ. Metabolic risk factors, endothelial dysfunction, and erectile dysfunction in men with diabetes. Am J Med Sci 2007; 334:466-480.

22. Taddei S, Virdis A, Mattei $P$, Ghiadoni L, Gennari A, Fasolo CB. Diabetes and endothelial function in normotensive subjects and patients with essential hypertension. Circul 1995; 91:1981- 1987

23. Hodek P, Trefil P, Stiborova M. Flavonoids- Potent and versatile biologically active compounds interacting with cytochrome $P$ 450. Chemico-Biol Int 2002; 139 (1):1-21.

24. Ferguson LR. Role of plant polyhenols in genomic stability Mutal Res 2001; 475: 89-111.

25. Goel A, Dani V, Dhawan DK. Protective effects of zinc on lipid peroxidation, antioxidant enzymes and hepatic histoarchitecture in chlorpyrifos-induced toxicity Chemico-Biol Int 2005; 156: 131-140. 